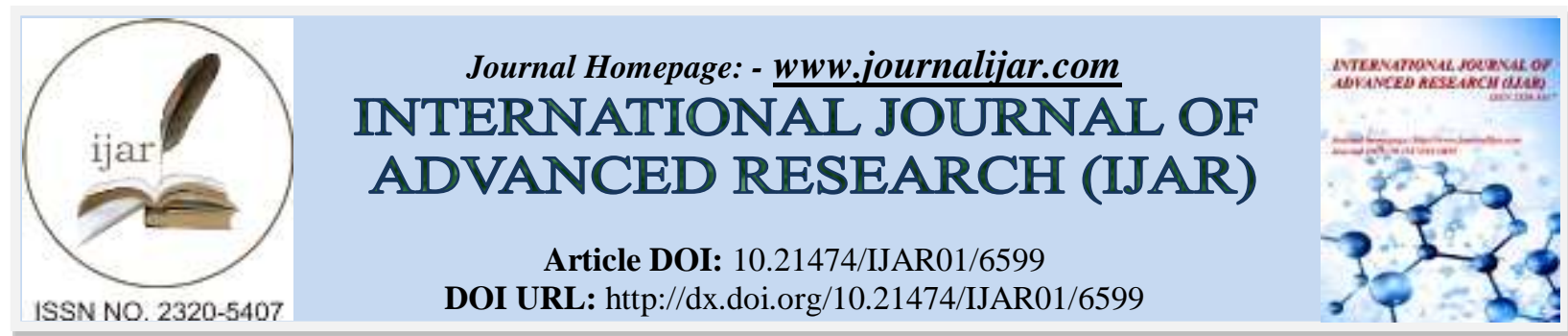

RESEARCH ARTICLE

\title{
AN EXPERIMENTAL STUDY TO EVALUATE THE EFFECTIVENESS OF AMLA JUICE AND HONEY ON IRON DEFICIENCY ANAEMIA AMONG SELECTED BATCH OF BSC NURSING STUDENTS OF GOVERNMENT COLLEGE OF NURSING FORT, BENGALURU.
}

Mrs. Joncy Joy and Dr. Prof Suvarna B Talwar.

\section{Manuscript Info}

Manuscript History

Received: 21 December 2017

Final Accepted: 23 January 2018

Published: February 2018

\section{Abstract}

Adolescence is a vulnerable period in the human life cycle for the development of nutritional anemia, which has been constantly neglected by public health programs. Girls are more likely to be a victim due to various reason. In a family with limited resources, the female child is more likely to be neglected. She is deprived of good food and education, and is utilized as an extra working hand to carry out the household chores. The added burden of menstrual blood loss, normal or abnormal, precipitates the crisis too often. Amla juice and honey as an alternative treatment to reduce anemia and to determine the effectiveness of amla juice with honey to improve the hemoglobin for the treatment of anemia of adolescent girls. Amla remains a popular tonic consumed across the Globe. Eating a Amla everyday also helps in improving hemoglobin in blood and curing Anemia. Objective: The main objective of the study were to assess the effectiveness of amla juice with honey to improve the hemoglobin level in adolescent girls with anemia. Methodology: The research design selected for the study was one group pretest-posttest design. A purposive sampling techniques was followed to obtain a sample of 25 selected batch of Bsc nursing students for experimental group and 25 selected batch of Bsc nursing students for control group who satisfied the inclusion criteria were included for the study. A digital hemoglobin meter was used for the study. Pre-test haemoglobin levels of both experimental and control group samples were checked using standardized digital haemoglobin meter. The investigator will do de-worming for the selected samples with antihelmintic, Tab. Albendazole 400mg before administration of amla juice and honey. Amla juice with honey is prepared by adding $100 \mathrm{gm}$ amla in $100 \mathrm{ml}$ of water and one teaspoon honey is added given to each student once in a day orally empty stomach to the experimental group for consecutive 21days and control group does not receive any treatment .Finally post test hemoglobin level was estimated using the same instrument. Ethical aspect of this study maintained throughout the study. The data were analyzed using descriptive and inferential statistics. Results: This study reveals that among the selected 25 samples, the pretest score in experimental group, $72 \%$ of adolescent girls were mild anemic ,28\% were moderate anemic, and nil was severe anemic. the post test score in experimental group,92\% of adolescent girls were mild anemic and $8 \%$ were moderate anemic. 
Hence there is an improvement in hemoglobin level after administration of Amla Juice with Honey in adolescent girls with anemia. This study reveals that among the selected 25 samples, the pretest score in control group, $60 \%$ of adolescent girls were mild anemic and $40 \%$ were moderate anemic. the post test score in control group, $48 \%$ of adolescent girls were mild anemic and 53\% were moderate anemic.Among Socio-demographic variables analyzed in experimental group, Father's educational status (9.008*), Mother's educational status $\left(7.176^{*}\right)$ were found significant with post test scores at 5\% level. Whereas in control group, Mother's educational status $(8.035 *)$ were found significant with post test scores at $5 \%$ level. Conclusion: The conclusion of the study shows that amla juice with honey found to be an effective alternative therapy in increasing hemoglobin level.

Copy Right, IJAR, 2018,. All rights reserved.

\section{Introduction:-}

"Life is magic, the way nature works seems to be quite magical" - Jonas Salk.

Anemia is one of the most important nutritional efficiencies affecting various social and socio-economic status. It is more common in developing countries with children and adolescent being at a significantly higher risk for the condition. Anemia is usually defined as a decrease in amount of red blood cells (RBCS) or the amount of hemoglobin in the blood. It can also be defined as a lowered ability of the blood to carry oxygen ${ }^{1}$.

World Health Organization (WHO) reports estimated that from $35 \%$ to $75 \%$ (56\% on average) of women in developing countries and $18 \%$ of women from industrialized countries are anemic ${ }^{2}$.

According to WHO there are 2 billion people affected with anemia, in India nearly 43,904,406 people are affected with anemia. In karnataka nearly $39 \%$ of women are affected and $69 \%$ are iron deficient, approximately 1200 women are affected with anemia. A study on prevalence of anemia among adolescent girls in 16 districts of India. A two-stage random method was used to select 30 cluster on the basis of probability proportional to size. Anemia was diagnosed by estimating the hemoglobin concentration in the blood with the use of the indirect cyanohemoglobin method. The survey data showed that the overall prevalence of anemia was $90.1 \%$, with $7.1 \%$ having severe anemia $^{3}$.

A report reveals that the prevalence of anemia was found to be $35.1 \%$. A significant association of anemia was found with socio economic status and literacy status of parents ${ }^{4}$.

A study found that $174(34.5 \%)$ of the 504 adolescent girls were anaemic. In his study he also found that the prevalence of anemia was significantly higher (45.2\%) among adolescent girls from joint families as compared to those from nuclear families $(28.3 \%)$, which may be related to household food security ${ }^{5}$.

A cross sectional study on the prevalence of iron deficiency anemia among university students in Noakhali region, Bangladesh. In the study 55.3\% students were found anemic of whom $36.7 \%$ were male and $63.3 \%$ were female. This study revealed that majority of university students, especially female, were anemic that might be aggravated by food habits and lack of awareness. The results suggest that anemia can be prevented by providing proper knowledge on the helpful diet, improved life style and harmful effect of anemia to the student $(\mathrm{p}=0.035)^{6}$.

A study found that $174(34.5 \%)$ of the 504 adolescent girls were anaemic. In his study he also found that the prevalence of anemia was significantly higher (45.2\%) among adolescent girls from joint families as compared to those from nuclear families $(28.3 \%)$, which may be related to household food security ${ }^{7}$.

Anemia can be managed by pharmacological and non-pharmacological treatment. Amla juice and honey is safe and better modality, good cost-effective non-pharmacological measures for improving haemoglobin level in blood. 


\section{Objectives Of The Study:-}

- To assess the degree of anemia among selected batch of Bsc nursing students in experimental group and control group.

- To evaluate the effectiveness of amla juice and honey among selected batch of bsc nursing students identified with iron deficiency anaemia.

- To find out the association between post-test score with selected demographic variables in both experimental group and control group.

\section{Methodology:-}

The research design selected for the study was one group pretest-posttest design. A purposive sampling techniques was followed to obtain a sample of 25 selected batch of Bsc nursing students for experimental group and 25 selected batch of Bsc nursing students for control group who satisfied the inclusion criteria were included for the study. A digital hemoglobin meter was used for the study. Pre-test haemoglobin levels of both experimental and control group samples were checked using standardized digital haemoglobin meter. The investigator will do de-worming for the selected samples with antihelmintic, Tab. Albendazole 400mg before administration of amla juice and honey . Amla juice with honey is prepared by adding $100 \mathrm{gm}$ amla in $100 \mathrm{ml}$ of water and one teaspoon honey is added given to each student once in a day orally empty stomach to the experimental group for consecutive 21 days and control group does not receive any treatment.

Finally post test hemoglobin level was estimated using the same instrument. Ethical aspect of this study maintained throughout the study. The data were analyzed using descriptive and inferential statistics.

\section{Results:-}

1. Degree of anemia among selected batch of Bsc nursing students in experimental group and control group.

Table:1a

\begin{tabular}{|l|l|l|l|l|}
\hline EXPERIMENT & \multicolumn{2}{|c|}{ PRE-TEST } & \multicolumn{2}{c|}{ POST-TEST } \\
\hline $\begin{array}{l}\text { 10-11gm/dl - Mild } \\
\text { anemia. }\end{array}$ & FREQUENCY & \multicolumn{1}{|c|}{ \% } & FREQUENCY & \% \\
\hline $\begin{array}{l}\text { 7-10gm/dl } \\
\text { Moderate anemia }\end{array}$ & 7 & 72 & 23 & 82 \\
\hline $\begin{array}{l}<\text { gm/dl - Severe } \\
\text { anemia }\end{array}$ & 0 & 28 & 2 & 33.3 \\
\hline Total & 0 & 0 & 100.0 \\
\hline
\end{tabular}

Table:1b

\begin{tabular}{|l|l|l|l|l|}
\hline CONTROL & \multicolumn{1}{|c|}{ PRE-TEST \% } & \multicolumn{2}{c|}{ POST-TEST } \\
\hline $\begin{array}{l}\text { 10-11gm/dl - Mild } \\
\text { anemia. }\end{array}$ & FREQUENCY & \multicolumn{1}{c|}{ FREQUENCY } & 48 \\
\hline $\begin{array}{l}\text { 7-10gm/dl } \\
\text { Moderate anemia }\end{array}$ & 10 & 60 & 12 & 53 \\
\hline $\begin{array}{l}<7 \text { gm/dl - Severe } \\
\text { anemia }\end{array}$ & 0 & 40 & 13 & 0 \\
\hline Total & 25 & 0 & 0 & 100.0 \\
\hline
\end{tabular}

2. Comparison of mean, standard deviation of amla juice and honey in experimental and control group.

Table:-2

\begin{tabular}{|c|c|c|c|c|c|c|c|}
\hline & \multicolumn{2}{|c|}{ Experiment } & \multicolumn{2}{|l|}{ Control } & \multirow{2}{*}{$\mathrm{t}$ value } & \multirow{2}{*}{ DF } & \multirow{2}{*}{$\begin{array}{l}\mathrm{P} \quad \text { value } \\
\text { Inference }\end{array}$} \\
\hline & Mean & SD & Mean & SD & & & \\
\hline Pre test & 10.524 & .8413 & 10.216 & 1.1003 & 1.112 & 48 & NS \\
\hline & & & & & & & \\
\hline & & & & & & & \\
\hline
\end{tabular}




\begin{tabular}{|l|l|l|l|l|l|l|l|}
\hline Post test & 11.368 & .9380 & 10.060 & .9967 & 4.779 & 48 & $\mathrm{P}<0.05^{*}$ \\
\hline & & & & & & & \\
\hline & & & & & & & \\
\hline
\end{tabular}

The calculated ' $t$ ' value is 4.779 is higher than the table value 2.021. Hence there is an improvement in hemoglobin level after administration of Amla Juice with Honey in adolescent girls with anemia.

Section 3a: Association between haemoglobin level with selected demographic variable in experimental group.

Table: 3a

\begin{tabular}{|c|c|c|c|c|c|c|c|}
\hline \multirow{3}{*}{$\begin{array}{l}\text { SL } \\
\text { NO }\end{array}$} & & & \multicolumn{5}{|c|}{ Haemoglobin level } \\
\hline & & & \multicolumn{2}{|c|}{ Median and below } & \multicolumn{2}{|c|}{ Above median } & \multirow{2}{*}{$\begin{array}{l}\text { Chi } \\
\text { square }\end{array}$} \\
\hline & & & $\mathbf{N}$ & $\%$ & $\mathbf{N}$ & $\%$ & \\
\hline \multirow[t]{3}{*}{1} & Age & 18 & 6 & 46.2 & 7 & 53.8 & $2.148 \mathrm{NS}$ \\
\hline & & 19 & 6 & 60.0 & 4 & 40.0 & $\mathrm{DF}=2$ \\
\hline & & 20 & 2 & 100.0 & 0 & 0.0 & \\
\hline \multirow[t]{4}{*}{2} & $\begin{array}{l}\text { Father's education } \\
\text { status }\end{array}$ & Illiterate & 5 & 83.3 & 1 & 16.7 & $9.008^{*}$ \\
\hline & & School Education & 3 & 25.0 & 9 & 75.0 & $\mathrm{DF}=2$ \\
\hline & & PUC & 6 & 85.7 & 1 & 14.3 & \\
\hline & & Degree \&Above & 0 & 0.0 & 0 & 0.0 & \\
\hline \multirow[t]{4}{*}{3} & $\begin{array}{l}\text { Mother's education } \\
\text { status }\end{array}$ & Illiterate & 9 & 81.8 & 2 & 18.2 & $7.176^{*}$ \\
\hline & & School Education & 2 & 22.2 & 7 & 77.8 & $\mathrm{DF}=2$ \\
\hline & & PUC & 3 & 60.0 & 2 & 40.0 & \\
\hline & & Degree \&Above & 0 & 0.0 & 0 & 0.0 & \\
\hline \multirow[t]{4}{*}{4} & Religion & Hindu & 9 & 56.3 & 7 & 43.8 & $0.903 \mathrm{NS}$ \\
\hline & & Christian & 4 & 50.0 & 4 & 50.0 & $\mathrm{DF}=2$ \\
\hline & & Muslim & 1 & 100.0 & 0 & 0.0 & \\
\hline & & Others & 0 & 0.0 & 0 & 0.0 & \\
\hline \multirow[t]{4}{*}{5} & $\begin{array}{l}\text { Family monthly } \\
\text { income }\end{array}$ & Rs3000-Rs6000 & 1 & 33.3 & 2 & 66.7 & $0.988 \mathrm{NS}$ \\
\hline & & Rs6000-Rs9000 & 10 & 62.5 & 6 & 37.5 & $\mathrm{DF}=2$ \\
\hline & & Rs9000-Rs 12000 & 3 & 50.0 & 3 & 50.0 & \\
\hline & & Rs12000\&Above & 0 & 0.0 & 0 & 0.0 & \\
\hline \multirow[t]{2}{*}{6} & $\begin{array}{l}\text { Pattern of } \\
\text { menstruation }\end{array}$ & Regular & 14 & 58.3 & 10 & 41.7 & $1.326 \mathrm{NS}$ \\
\hline & & Irregular & 0 & 0.0 & 1 & 100.0 & $\mathrm{DF}=1$ \\
\hline \multirow[t]{2}{*}{7} & Diet pattern & Vegetarian & 1 & 50.0 & 1 & 50.0 & $0.032 \mathrm{NS}$ \\
\hline & & Mixed & 13 & 56.5 & 10 & 43.5 & $\mathrm{DF}=1$ \\
\hline \multirow[t]{2}{*}{8} & Physical activity & Yes & 2 & 66.7 & 1 & 33.3 & $0.157 \mathrm{NS}$ \\
\hline & & No & 12 & 54.5 & 10 & 45.5 & \\
\hline
\end{tabular}

The result shows, Father's educational status $\left(9.008^{*}\right)$, Mother's educational status $\left(7.176^{*}\right)$ were found significant with post test scores at 5\% level. There was no significant association between age in years (2.148), religion (0.903), Family monthly income (0.988), Pattern of menstruation (1.326), diet pattern (0.032), and physical activity(0.157) and the post-test scores. 
Section: 3b Association between haemoglobin level with selected demographic variable in control group Table: 3b

\begin{tabular}{|c|c|c|c|c|c|c|c|}
\hline \multirow{3}{*}{$\begin{array}{l}\mathrm{SL} \\
\mathrm{NO} \\
\end{array}$} & & & \multicolumn{5}{|c|}{ haemoglobin level } \\
\hline & & & \multicolumn{2}{|c|}{ Median and below } & \multicolumn{2}{|c|}{ Above median } & \multirow[t]{2}{*}{ Chi square } \\
\hline & & & $\mathbf{N}$ & $\%$ & $\mathbf{N}$ & $\%$ & \\
\hline \multirow[t]{3}{*}{1} & Age & 18 & 6 & 46.2 & 7 & 53.8 & $0.438 \mathrm{NS}$ \\
\hline & & 19 & 6 & 60.0 & 4 & 40.0 & $\mathrm{DF}=2$ \\
\hline & & 20 & 1 & 50.0 & 1 & 50.0 & \\
\hline \multirow[t]{4}{*}{2} & Father's education status & Illiterate & 4 & 40.0 & 6 & 60.0 & $5.769 \mathrm{NS}$ \\
\hline & & School Education & 8 & 80.0 & 2 & 20.0 & $\mathrm{DF}=2$ \\
\hline & & PUC & 1 & 20.0 & 4 & 80.0 & \\
\hline & & Degree \&Above & 0 & 0.0 & 0 & 0.0 & \\
\hline \multirow[t]{4}{*}{3} & $\begin{array}{l}\text { Mother's education } \\
\text { status }\end{array}$ & Illiterate & 8 & 88.9 & 1 & 11.1 & $8.035^{*}$ \\
\hline & & School Education & 4 & 36.4 & 7 & 63.6 & $\mathrm{DF}=2$ \\
\hline & & PUC & 1 & 20.0 & 4 & 80.0 & \\
\hline & & Degree \&Above & 0 & 0.0 & 0 & 0.0 & \\
\hline \multirow[t]{4}{*}{4} & Religion & Hindu & 6 & 46.2 & 7 & 53.8 & $2.04 \mathrm{NS}$ \\
\hline & & Christian & 5 & 50.0 & 5 & 50.0 & $\mathrm{DF}=2$ \\
\hline & & Muslim & 2 & 100.0 & 0 & 0.0 & \\
\hline & & Others & 0 & 0.0 & 0 & 0.0 & \\
\hline \multirow[t]{4}{*}{5} & Family monthly income & Rs3000-Rs6000 & 5 & 55.6 & 4 & 44.4 & $3.276 \mathrm{NS}$ \\
\hline & & Rs6000-Rs9000 & 6 & 60.0 & 4 & 40.0 & $\mathrm{DF}=3$ \\
\hline & & Rs9000-Rs12000 & 1 & 20.0 & 4 & 80.0 & \\
\hline & & Rs12000\&Above & 1 & 100.0 & 0 & 0.0 & \\
\hline \multirow[t]{2}{*}{6} & Pattern of menstruation & Regular & 13 & 56.5 & 10 & 43.5 & $2.355 \mathrm{NS}$ \\
\hline & & Irregular & 0 & 0.0 & 2 & 100.0 & $\mathrm{DF}=1$ \\
\hline \multirow[t]{2}{*}{7} & Diet pattern & Vegetarian & 1 & 50.0 & 1 & 50.0 & $0.003 \mathrm{NS}$ \\
\hline & & Mixed & 12 & 52.2 & 11 & 47.8 & $\mathrm{DF}=1$ \\
\hline \multirow[t]{2}{*}{8} & Physical activity & Yes & 1 & 50.0 & 1 & 50.0 & $0.003 \mathrm{NS}$ \\
\hline & & No & 12 & 52.2 & 11 & 47.8 & \\
\hline
\end{tabular}

The results revealed, Mother's educational status $\left(8.035^{*}\right)$ were found significant with post test scores at $5 \%$ level. There was no significant association between age in years (0.438), Father's educational status (5.769) religion (2.04), Family monthly income (3.276), Pattern of menstruation (2.355), diet pattern (0.003), and physical activity $(0.003)$ and the post-test scores.

\section{Discussion:-}

The present study confirms that in experimental group, The pre test mean value is 10.524 and pre test SD is .8413 . In control group, The pre test mean value is 10.216 and pre test SD is 1.1003 . The calculated ' $t$ ' value is 1.112 is less than the table value 2.021 .

In experimental group,The post test mean value is 11.368 and post test SD is .9380 and In control group, The post test mean value is 10.060 and post test SD is .9967 . The calculated ' $t$ ' value is 4.779 is higher than the table value 2.021. Hence there is an improvement in hemoglobin level after administration of Amla Juice with Honey in adolescent girls with anemia.

The present study revealed,there is significant association between Father's educational status and Mother's educational status. But the study also revealed there is no association between socio-demographic variables such age in years ,religion ,Family monthly income, Pattern of menstruation, diet pattern and physical activity and the post test scores. 


\section{Conclusion:-}

The conclusion drawn from the findings of the study are as Amla juice and honey are found to be an effective nursing intervention in increasing hemoglobin level.Amla juice and honey are found to have no side effects when compared with other pharmacological treatment.Samples satisfaction is very much higher in this intervention.

\section{Nursing Implication:}

The findings of the study reveal the implication on nursing practice, nursing education, nursing research and nursing administration.

\section{Nursing Practice:}

Amla juice and honey is a safe and better modality which bring a higher level of satisfaction for adolescent girls. This intervention could bring benefits to both adolescent girls who are on pharmacological therapy and not on the same.It also brings a long term effect and higher level of improvement of hemoglobin level, thus the samples feels better and can avoid complication.

\section{Nursing Education:}

This study can motivate student nurse to explore new strategies for effective improvement of hemoglobin level in blood.This research report can be kept in library for reference of nursing personnel and other health care professionals. The nurse educator can take independent decision based on principles of health care.Nurse educator can train and encourage the student nurses to implement amla juice and honey as a non-pharmacological management.

\section{Nursing Research:}

The nursing implication of the study lies in the scope for expanding the quality of nursing service. In this area of evidence based practice, publication of these studies will take nursing to a new horizon.Nurse researcher can do various studies related to effectiveness of amla juice and honey for improving hemoglobin level among antenatal mother.A comparative study can be done to determine the effectiveness of amla juice and honey with other intervention.Similar study can be conducted on a large sample so it could be generalized.

\section{Nursing Administration:}

The result of the study encourages the nurse administrator to conduct In service education programs on various types of non-pharmacological treatment to increasing the hemoglobin level.This helps the nurse administrator to develop and provide an effective non-pharmacological measures for improving hemoglobin level.Nurse administrators can create awareness among nurses that amla juice and honey is a very good cost-effective nursing intervention to increasing hemoglobin level in blood.

\section{Limitation:-}

1. The sample size of adolescent girls was 50 and hence generalization is not possible.

2. The data collection period was only 1 month.

3. The study is limited only to the adolescent girls studying in Government college of nursing at Bengaluru during the period of data collection.

4. Extraneous variables are controlled to some extent only.

\section{Recommendations:-}

1. The study may be replicated with randomization in selection of a large sample.

2. Nurse researcher can do studies related to other type of alternative therapies in improving hemoglobin level.

3. A study can be conducted by including more number of variables and at different geographic locations.

4. The study can be conducted to compare the degree of anemia among adolescent girls living in urban and rural areas.

\section{Summary:-}

This chapter dealth with the findings, conclusion, nursing implication, limitation and recommendations of the study. 


\section{Bibliography:-}

1. Watson's (1999). Medical and Surgical Nursing and Related Physiology. $4^{\text {th }}$ edition. W.B. Saunders Company Publication. Page no 246-254.

2. The Indian Journal of India, June 2010, Vol:8, page No : 48-49

3. Toteja G.S. Singh P, Dhillon BS, Saxena BN, Ahmed FU, Singh RP. Indian Journal of Community Medicine, 2006, Vol: 27, Page No: 311 -315.

4. Chaudhary SM, Dhage VR, A study of anemia among adolescent female in Urban area. Indian Journal of Community Medicine 2008, October, Vol: 33(4) Page No : 243 - 245.

5. Rawat CMS, Garg SK, Singh JV, Bhatnagar M Indian Journal of Community Medicine 2001, Vol : 26, Page 173-175.

6. Shill K B, Kamakar, prevalence of iron deficiency anemia among university students in Noakhali region, Bangladesh. Indian Journal of Community Medicine, Indian I Community Med. Oct. 2008, Vol:A, Page No : 243-245.

7. Pastides, Kaur S, Deshmukh PR, Garg BS, Nutritional anemia in adolescent girls of rural area. India Journal community medicine 2006, Vol : 31, Page : $255-258$.

8. Shilpa S. Biradar et al, Prevalence of Anaemia among Adolescent Girls. Journal of clinical and diagnostic research, 2012, Vol: 6, Page: $372-377$.

9. Nalluri. Kranthi Koushik.et al, World Journal of Pharmacy and Pharmaceutical Sciences ,Vol: 3,, Page 827836

10. Meenal VK, Durge PM, Kasturwar NB. Prevalence of Anemia among Adolescent Girls in an Urban Slum. National Journal of Community Medicine. Jan-March 2012; 3-1.

11. Siddharam S M, Venketesh G M, Thejeshwari H L. A Study of Anemia among Adolescent Girls in Rural Area of Hassan district, Karnataka, South India. International Journal of Biological and Medical Research. 2011; 2(4): $922-924$.

12. Wankhade et. al. prevalence of anaemia, a common low haemoglobin condition, in young female population of Aurangabad region (MS). International Journal of Medical and Pharmaceutical Sciences. 2011; 1:4. 